\title{
PENGARUH MODEL PEMBELAJARAN LEARNING CYCLE 5E TERHADAP PENINGKTAN MINAT DAN HASIL BELAJAR PESERTA DIDIK DI SMA NEGERI 8 MATARAN TAHUN AJARAN 2018/2019
}

\author{
Yuyun Susanti, Ahmad Zohdi, Lalu Ahmad Didik Meiliyadi \\ Program Studi Tadris Fisika, FTK Universitas Islam Negeri Mataram \\ Korespondensi: yuyunsusanti36@gmail.com.id
}

\begin{abstract}
Abstrak: Penelitian ini bertujuan untuk mengetahui pengaruh model pembelajaran learning cycle $5 E$ terhadap peningkatan minat dan hasil belajar peserta didik di SMA Negeri 8 Mataram Tahun Ajaran 2018/2019. Jenis penelitian yang digunakan adalah penelitian quasi eksperiment. Teknik pengumpulan data dengan menggunakan tes, angket dan dokumentasi. Berdasarkan hasil tes awal diperoleh rata-rata kelas eksperimen sebesar 52,39 dan kelas control sebesar 47,91. Hasil tes akhir menunjukan rata-rata kelas ekperimen sebesar 81,93 dan kelas kontrol 71,34. Data tes akhir peserta didik kelas sampel dianalisis menggunakan uji-t. Berdasarkan hasil analisis data menggunakan uji-t diperoleh $t_{\text {hitung }}$ sebesar 3,78 dan $t_{\text {tabel }}$ pada taraf signifikan 5\% sebesar 2,000, maka $t_{\text {hitung }}>t_{\text {tabel. }}$ Maka dapat disimpulkan bahwa terdapat pengaruh model Learning Cycle $5 E$ terhadap peningkatan minat dan hasil belajar peserta didik kelas XI di SMA Negeri 8 Mataram Tahun Ajaran 2018/2019.
\end{abstract}

Kata Kunci: Pembelajaran Learning Cycle 5e, Minat Belajar, Hasil Belajar.

\section{THE INFLUENCE OF 5E LEARNING CYCLE MODEL TRHOUGH INTEREST AND LEARNING OUTCOMES STUIDENTS AT SMA NEGERI 8 MATARAM IN ACADEMIC YEAR 2018/2019}

\begin{abstract}
This study aims to determine the effect of the 5E learning cycle learning model to increase student interest and learning outcomes at SMA Negeri 8 Mataram insearch academic year 2018/2019. This type of research is a quasi experimental study. Data collection techniques used tests, questionnaires and documentation. Based on preliminary test results obtained an average of experimental class of 52,39 and control class of 47,91. Result showed an average of 81,93 experimental classes and 71,34 control classes. Final test data of sample class student were analyzed using t-test. Based on the results of data analysis used the t-test obtained tcount of 3,78 and ttable at a significant level of $5 \%$ of 2,000 , then tcount $>$ ttable. Then it can be concluded that there is an effect of the 5E Learning Cycle model to increase on interest and learning outcomes of class XI students in SMA Negeri 8 Mataram 2018/2019 Academic year.
\end{abstract}

Keywords: 5e Learning Cycle, Learning Interest, Learning Outcomes.

\section{PENDAHULUAN}

Mata pelajaran fisika merupakan salah satu cabang IPA yang mengkaji tentang berbagai fenomena alam dan memegang peranan yang sangat penting dalam perkembangan sains, teknologi dan konsep hidup harmonis dengan alam. Fisika sebagai salah satu disiplin ilmu yang 
mana aspek penalaran maupun aspek terapannya sangat penting dalam upaya penguasaan ilmu pengetahuan dan teknologi. Sebagian besar masyarakat Indonesia menganggap bahwa Fisika adalah ilmu yang sangat sulit. Pandangan yang demikian itulah yang menyebabkan banyak siswa yang tidak berminat dengan pelajaran Fisika yang akhirnya berimplikasi pada rendahnya hasil belajar fisika siswa. Keterlibatan siswa secara aktif dalam proses pembelajaran mendukung siswa untuk membangun pengetahuannya sendiri, sehingga pembelajaran akan berpusat pada siswa (student centered) dan bukan pada guru (teacher centered).

Menurut teori konstruktivisme, salah satu prinsip yang paling penting dalam psikologi pendidikan adalah bahwa guru tidak hanya sekedar memberikan pengetahuan kepada siswa, tetapi siswa harus membangun sendiri pengetahuan di dalam benaknya. Guru dapat memberikan kemudahan dengan memberi kesempatan siswa untuk menemukan atau menerapkan ide-ide mereka sendiri dan mengajar siswa menjadi sadar dan secara sadar menggunakan strategi mereka sendiri untuk belajar. Belajar adalah suatu proses di mana dalam proses tersebut terjadi interaksi baik antar individu maupun dengan lingkungannya sehingga membentuk suatu pengalaman tertentu yang mampu menghasilkan perubahan tingkah laku berupa kecakapan, sikap, kebiasaan, dan kepribadian. Keberhasilan belajar ditentukan oleh beberapa faktor yang salah satunya adalah minat belajar. Minat adalah rasa lebih suka dan rasa keterikatan pada suatu hal atau aktifitas, tanpa ada yang menyuruh. Minat pada dasarnya tidak dibawa sejak lahir, melainkan diperoleh kemudian. Untuk menciptakan suasana pembelajaran sebagaimana disebutkan di atas, pemilihan model pembelajaran yang tepat sangat diperlukan. Dengan kata lain, model pembelajaran merupakan bungkus atau bingkai dari penerapan suatu pendekatan, metode, dan teknik pembelajaran. Oleh karena itu, guru dituntut mampu menerapkan model pembelajaran yang tepat untuk memotivasi siswa dalam belajar sehingga mampu mencapai tujuan pembelajaran yang telah ditetapkan.

Berdasarkan hasil observasi awal dan wawancara dengan salah satu guru mata pelajaran fisika dan salah satu siswa di SMA Negeri 8 Mataram 2018/2019, selama ini guru masih menggunakan metode ceramah (konvensional). Pemblajaran berlangsung masih konvensional dengan latihan soal atau rumus-rumus tanpa mengkaitkan dengan praktik dalam kehidupan sehari-hari. Hal tersebut menimbulkan permasalahan yang diindikasikan sebagai faktor penyebab minat belajar dan hasil belajar fisika siswa kurang maksimal, terlihat bahwa peserta didik lebih banyak diam dan hanya mendengarkan pembelajaran, tidak aktif dalam proses pembelajaran, rasa ingin tahu mereka kurang tentang materi yang dipelajari, hanya sedikit peserta didik yang menunjukkan keaktifan berpendapat dan bertanya. Alat ukur yang digunakan untuk mengetahui pemahaman konsep fisika peserta didik dilakukan dengan cara mengevaluasi setiap akhir materi dalam bentuk tes uraian. Hal ini ditunjukan oleh data hasil wawancara yang diperoleh dari guru fisika rata-rata tidak memenuhi standar kelulusan yang ditetapkan. Dimana KKM yang telah ditetapkan di sekolah 75 sedangkan hasil yang diperoleh peserta didik tidak mencapai KKM. Hal ini menuntut guru lebih kreatif dalam menerapkan metode dan model pembelajaran yang tepat sebagai upaya meningkatkan kualitas kegiatan pembelajaran fisika. Guru memiliki peran dan tanggung jawab yang sangat besar dalam mencapai tujuan pembelajaran yang telah dirumuskan. Namun pencapaian tujuan pembelajaran juga dipengaruhi oleh berbagai faktor, salah satu diantaranya adalah model pembelajaran yang digunakan. Keberhasilan dari suatu proses belajar seorang siswa dapat dilihat dari prestasi belajar yang dihasilkan. Prestasi belajar selalu identik dengan hasil belajar berupa nilai kognitif, yang dapat dilihat dari perubahan 
tingkah laku, berupa psikomotor yang terjadi pada diri seseorang setelah orang tersebut melakukan kegiatan belajar.

Sehingga dari observasi awal yang telah dilakukan penggunaan siklus belajar (Learning Cycle 5E) memberikan kesempatan bagi siswa untuk mengungkapkan pengetahuan sebelumnya dan kesempatan untuk menyanggah, mendebat gagasan- gagasan mereka, proses ini menghasilkan ketidakseimbangan kognitif, sehingga mengembangkan tingkat penalaran yang lebih tinggi, dan merupakan suatu pendekatan yang baik untuk pembelajaran sains. Berdasarkan latar belakang di atas maka penulis ingin meneliti tentang Pengaruh Model Pembelajaran Learning Cycle $5 E$ terhadap Peningkatan Minat dan Hasil Belajar Peserta Didik Kelas XI SMA Negeri 8 Mataram Tahun Ajaran 2018/2019.

\section{METODE}

Adapaun jenis penelitian yang digunakan dalam penelitian ini adalah quasi eksperiment. Metode quasi eksperiment merupakan metode penelitian yang mempunyai kelompok kontrol, tetapi tidak dapat sepenuhnya untuk mengontrol variabel-variabel luar yang mempengaruhi pelaksanaan eksperimen. Pendekatan penelitian yang digunakan dalam penelitian ini adalah pendekatan kuantitatif dimana dalam penelitian kuantitatif adalah penelitian yang berlandaskan pada filsafat positivisme, digunakan untuk meneliti pada populasi dan sampel tertentu, teknik pengambilan sampel pada umumnya dilakukan secara random, pengumpulan data menggunakan instrumen penelitian, analisis data bersifat kuantitatif/statistik dengan tujuan untuk menguji hipotesis yang telah diterapkan. Desain penelitian yang digunakan adalah pretest-posttest control group design. Kelompok ekperimen dalam penelitian ini diberi perlakuan dengan menggunakan model pembelajaran

learning cycle $5 E(\mathrm{X})$, sedangkan kelompok kontrol diberi perlakuan dengan menggunakan model konvensional. Adapun instrument yang digunakan dalam penelitian ini yaitu Instrumen tes dan angket.

\section{HASIL DAN PEMBAHASAN}

\section{Hasil}

Dalam suatu penelitian, peran penyajian data sangat penting. Karena penyajian data merupakan salah satu bukti bahwa kita sudah melakukan penelitian, disamping itu juga sebagai penunjang keberhasilan dalam penelitian. Data dalam penelitian ini berupa data hasil belajar peserta didik yang ditunjukkan dengan nilai tes awal dan tes akhir. Pengambilan data untuk nilai tes awal dan tes akhir menggunakan instrument pengumpulan data yang berupa tes objektif sebanyak 30 soal yang sudah divalidator.

\section{1) Data Hasil Tes Awal}

Pengambilan data pada tes awal untuk mengetahui kemampuan awal peserta didik kelas XI SMA Negeri 8 Mataram dalam memahami pokok bahasan alat-alat optik. Pengambilan data untuk tes awal menggunakan instrumen pengumpulan data yang berupa tes objektif sebanyak 30 soal yang diberikan kepada peserta didik sehingga dapat menegtahui kemampuan awal peserta 
didik tersebut. Rata-rata nilai kemampuan awal hasil belajar ssebesar 52,39 standar deviasinya sebesar 9,96. Nilai kemampuan hasil belajar terendah yang diperoleh sebesar 27 dan nilai tertinggi sebesar 67. Sedangkan pada kelas kontrol niali rata-rata sebesar 47,90, standar deviasinya sebesar 10,14. Nilai kemampuan hasil belajar terendah yang diperoleh sebesar 27 dari dan nilai kemampuan hasil belajar tertinggi yang diperoleh sebesar 67. Adapun data-data yang diperoleh disajikan dalam tabel 1:

Tabel 1 Data Hasil Tes Awal

\begin{tabular}{cccccccc}
\hline No & Kelas & $\sum \mathrm{X}$ & $\sum \mathrm{X}^{2}$ & $\overline{\mathrm{X}}$ & $\mathrm{Sd}^{2}$ & $\begin{array}{c}\text { Nilai } \\
\text { Max }\end{array}$ & Nilai Min \\
\hline 1 & Eksperimen & 1729 & 93765 & 52,39 & 9,96 & 67 & 27 \\
2 & kontrol & 1533 & 76629 & 47,90 & 10,14 & 67 & 27 \\
\hline
\end{tabular}

2) Data Hasil Tes Akhir

Setelah diberikan perlakuan pada kedua kelas sampel dilakukan tes akhir (post-test). Adapun data-data yang diperoleh disajikan dalam tabel 2

Tabel 2 Data Hasil Tes Akhir

\begin{tabular}{cccccccc}
\hline No & Kelas & $\sum \mathrm{X}$ & $\sum \mathrm{X}^{2}$ & $\overline{\mathrm{X}}$ & $\mathrm{Sd}^{2}$ & $\begin{array}{c}\text { Nilai } \\
\text { Max }\end{array}$ & $\begin{array}{c}\text { Nilai } \\
\text { Min }\end{array}$ \\
\hline 1 & Eksperimen & 2704 & 226540 & 81,93 & 12,47 & 97 & 50 \\
2 & kontrol & 2283 & 166213 & 71,34 & 10,37 & 90 & 50 \\
\hline
\end{tabular}

Tabel 2 menunjukkan nilai statistik deskripitif perolehan nilai kemampuan hasil belajar setelah diberikan perlakuan pada kelas eksperimen dan kelas kontrol, maka diperoleh bahwa pada kelas eksperimen dengan banyak responden 33 peserta didik yang diberi perlakuan model pembelajaran learning cycle $5 E$ diperoleh rata-rata nilai kemampuan hasil belajar ssebesar 81,93 standar deviasinya sebesar 12,47. Nilai kemampuan hasil belajar terendah yang diperoleh sebesar 50 dan nilai tertinggi sebesar 97. Nilai kemampuan hasil belajar peserta didik kelas kontrol dengan banyak responden 32 peserta didik yang tidak diberikan perlakuan model pembelajaran learning cycle $5 E$ diperoleh rata-rata nilai tes 71,34 , standar deviasinya sebesar 10.37. Nilai kemampuan hasil belajar terendah yang diperoleh sebesar 50 dari dan nilai kemampuan hasil belajar tertinggi yang diperoleh sebesar 90 .

3) Angket

Angket merupakan salah satu jenis instrumen pengumpulan data untuk mengetahui tingkat minat peserta didik dengan penerapan model pembelajaran learning cycle 5E. Angket 
diberikan kepada responden yaitu kelas kontrol dan kelas eksperimen pada akhir pelaksanaan kegiatan belajar mengajar dengan penerapan model learning cycle 5E. Butir instrumen angket yang digunakan sebanyak 30 dengan alternatif jawaban sebanyak 4 opsi. Adapun dalam angket digunakan kalimat positif dan kalimat negatif.

Berdasarkan pengisian angket para responden diperoleh hasil dari responden yakni kelas ekesperimen diketahui bahwa tingkat minat belajar peserta didik pada penerapan model pembelajaran learning cycle 5E adalah kategori sangat berminat dibandingkan kelas kontrol yang diterapkan metode konvensional. Adapun data-data yang diperoleh disajikan dalam tabel berikut ini:

Tabel 3 Data Hasil Angket

\begin{tabular}{ccccccc}
\hline No & Kelas & $\sum \mathrm{X}$ & $\sum \mathrm{X}^{2}$ & $\overline{\mathrm{X}}$ & Nilai Max & Nilai Min \\
\hline 1 & Eksperimen & 2748 & 229778 & 83,27 & 98 & 76 \\
2 & kontrol & 2471 & 192183 & 77,21 & 97 & 66 \\
\hline
\end{tabular}

Berdasarkan hasil analisis data dilihat dari test awal, akhir dan nilai angket dapat di interperstasikan pada grafik dibawah ini:

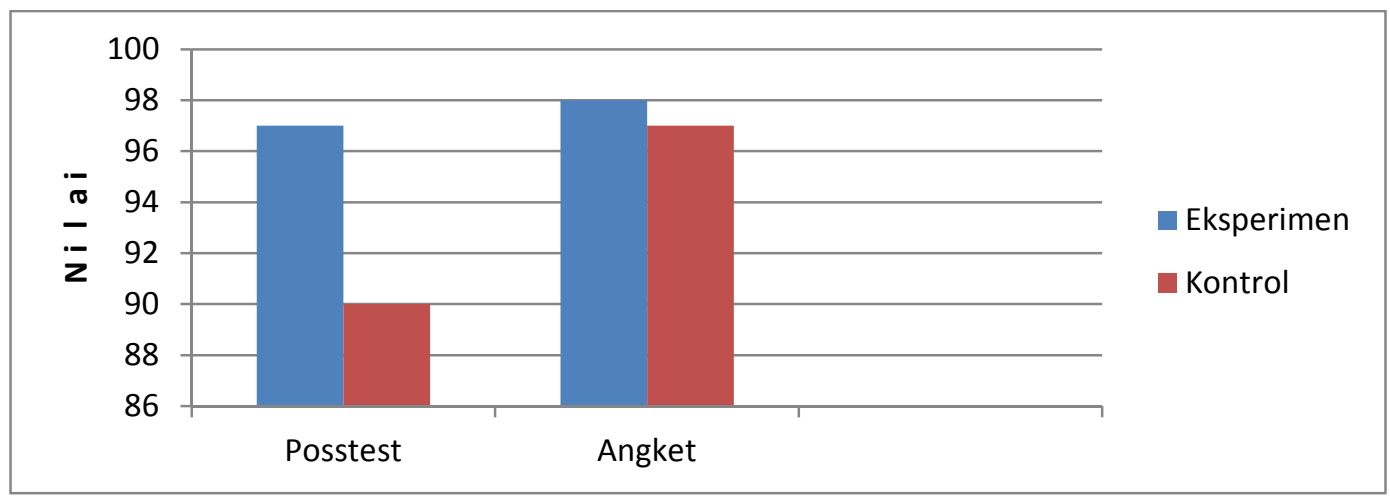

Gambar 1 Grafik Hasil Angket

\section{Pembahasan}

Upaya untuk pembangunan kualitas sumber daya manusia di Indonesia terus dilakukan melalui berbagai institusi pendidikan dengan cara menerapkan berbagai inovasi-inovasi yang baru, baik inovasi dalam hal teknologi maupun inovasi dalam hal pembelajaran. Inovasi dalam proses belajar mengajar salah satunya adalah inovasi yang bisa dilakukan oleh guru dalam penerapan berbagai jenis inovasi dalam pembelajaran. Dalam proses belajar mengajar guru harus memiliki inovasi baik berupa metode atau model pembelajaran yang beragam agar peserta didik dapat efektif dan efisisen dalam belajar, sehingga dapat berdampak positif terhadap minat dan hasil belajar yang dilakukan, khususnya dalam proses belajar di dalam kelas. Selain itu Guru 
harus pandai dalam memposisikan penggunaan metode atau model pembelajaran agar waktu yang digunakan efisien sehingga membuat peserta didik senang dalam belajar.

Dalam penelitian ini model pembelajaran learning cycle $5 E$ merupakan suatu inovasi yang baru dalam pembelajaran, khususnya pada pelajaran fisika. Penggunaan model pembelajaran learning cycle $5 E$ merupakan model pembelajaran yang melibatkan peserta didik secara aktif pada saat proses belajar dan peserta didik mengakses pengetahuan awal yang telah dimiliki serta memecahkan masalah itu sendiri baik secara individu maupun kelompok. Dibandingkan dengan pembelajaran konvensional yaitu pembelajaran biasa dipakai guru yang cenderung bersifat klasikal dan dilaksanakan dengan tatap muka. Berikut ini akan disampaikan pembahasan dari hasil penelitian yang telah dianalisis.

Hasil Penelitian yang dilaksanakan di SMA Negeri 8 Mataram. Pelaksanaan peneliti ini dilakukan pada dua kelas yakni kelas XI MIA 3 sebagai kelas eksperimen dan kelas XI MIA1 sebagai kelas control. Setelah diadakan uji hipotesis dengan uji-t pada taraf signifikan 5\% diperoleh bahwa $t_{\text {hitung }}<t_{\text {tabel }}$ dengan demikian H0 ditolak dan Ha diterima. Dengan demikian hipotesis bahwa Pembelajaran learning cycle 5E dapat meningkatkan minat dan hasil belajar peserta didik kelas XI SMA Negeri 8 Mataram dapat diterima.

Berdasarkan data hasil tes akhir siswa (post-test) dapat dilihat dari rata-rata kelas eksperimen adalah 81,93 sedangkan rata-rata kelas kontrol adalah 71,34 perbedaan tersebut disebabkan karena pada kelas eksperimen, peserta didik lebih antusias dalam belajar sedangkan guru mampu menciptakan suasana belajar yang menyenangkan, serta siswa yang lebih berperan aktif dalam berlangsung pembelajaran dikelas. Guru menggunakan model pembelajaran learning cycle $5 E$ yakni pembelajaran yang dimulai dari pembangkitan minat, kemudian para peserta didik diorganisasikan dalam suatu kelompok kecil. Dalam kelompok tersebut, peserta didik menjelaskan permasalahan dengan bahasa dan kalimat mereka sendiri sesuai dengan pengetahuan yang dimiliki, serta mengembangkan konsep dan keterampilan diri peserta didik. Pada tahap inilah kemampuan hasil belajar peserta didik dilatih, peserti didik dituntut untuk menyelesaikan masalah tersebut dengan cara yang sederhana. Hal ini menandakan bahwa peserta didik mempunyai kemampuan untuk meningkatkan hasil belajar . Sedangkan pada kelas kontrol tidak terjadi peningkatan secara signifikan dapat kita lihat dari nilai rata-rata 71,34, dimana pada kelas kontrol antusias peserta didik dalam belajar kurang disebabkan karena siswa kurang aktif dalam belajar, kurang mendapatkan perhatian dari guru, banyak yang bicara sendiri ketika pembelajaran berlangsung. Faktor guru juga berpengaruh dalam kelas kontrol, guru masih menggunakan metode pembelajaran konvesional yaitu metode ceramah, sehingga membuat siswa merasa bosan ketika berada didalam kelas.

Peningkatan hasil belajar pada kelas eksperimen disebabkan karena pembelajaran dengan menggunakan model pembelajaran learning cycle $5 E$ peserta didik lebih mudah memahami materi yang diberikan, peserta didik dapat bekerja secara kelompok sesuai kemampua yang dimiliki, lebih aktif dan berminat dalam proses pembelajaran. Selain itu, adanya keterbukaan siswa untuk mengungkapkan pertanyaan atau kesulitan dalam memahami materi pelajaran membuat hasil belajarnya meningkat. Dalam hal ini, guru menanggapi dan berusaha memahami permasalahan siswa serta menjelaskan tentang hal-hal yang belum dimengerti. Pada akhirnya guru mengevaluasi kembali materi pelajaran yang telah dipelajari untuk mengetahui sejauh mana pemahaman siswa terhadap materi yang disajikan. 
Dari analisis data terdapat hubungan antara Minat Belajar dengan Hasil Belajar peserta didik Pada Mata Pelajaran Fisika Kelas XI SMA Negeri 8 Mataram” bisa diterima. Dengan kata lain mianat belajar peserta didik mempunyai hubungan dengan hasil belajar peserta didik, karena hasil belajar yang dicapai oleh peserta didik tidak terlepas dari minat belajar peserta didik tersebut. Hasil dalam penelitian ini menegaskan bahwa nilai rata-rata minat belajar sebesar 83,27 . Hal ini dibuktikan melalui uji t hasil $r_{\text {hitung }}$ lebih besar daripada $r_{\text {tabel }}(4,09>2,000)$. Sedangkan hasil belajar dengan nilai rata-rata sebesar 81,93 dibuktikan melalui uji t $(3,78$ $>2,000)$.

Meningkatnya minat belajar siswa juga disebabkan karena ketertarikan siswa yang tinggi dalam belajar tentang pelajaranya. Bahwa belajar merupakan tindakan dan prilaku siswa yang kompleks. Sebagai tindakan, maka belajar hanya dialami oleh siswa sendiri. Siswa adalah penentu terjadinya atau tidak terjadinya proses belajar dan proses belajar terjadi berkat siswa memperoleh sesuatu yang ada di lingkungan sekitar itu sendiri. Hasil ini memperjelas bahwa terdapat hubungan motivasi belajar dengan hasil belajar yang akan dapat mempengaruhui satu sama lain. Proses pembelajaran menggunakan model pembelajaran learning cycle $5 E$ yang dilakukan pada penelitian ini pada dasarnya adalah proses interaksi, baik interaksi antar siswa, dan siswa dengan guru. Pembelajaran sebagai proses interaksi artinya menempatkan guru bukan sebagai sumber belajar. Hal inilah yang membuat siswa aktif didalam keingintahuannya tentang materi atau permasalahan yang tersaji.

Berdasarkan hasil analisis data yang telah dilakukan, diperoleh bahwa hasil belajar peserta didik yang diberi model pembelajaran learning cycle 5E telah mencapai ketuntasan belajar secara meningkat, rata-rata hasil belajar tersebut lebih tinggi dari pada rata-rata hasil belajar yang diterapkan metode konvensional, dan peningkatan minat belajar peserta didik yang diberi model pembelajaran learning cycle 5E lebih tinggi dari pada peningkatan minat belajar yang diberi metode konvensional. Oleh karena itu, dapat disimpulkan bahwa model pembelajaran learning cycle 5E berpengaruh terhadap peningkatan minat dan hasil belajar peserta didik kelas XI di SMA Negeri 8 Mataram tahun ajaran 2018/2019.

\section{PENUTUP}

Berdasarkan hasil analisis data dan pembahasan dalam penelitian ini dengan menggunakan uji-t diperoleh $t_{\text {tabel }}=2.000$ dan $t_{\text {hitung }}=3,78$ maka diketahui nilai $t_{\text {hitung }}(3,78)>$ $\mathrm{t}_{\text {tabel }}(2,000)$ dengan $\mathrm{dk}$ yang besarnya $\mathrm{dk}=\mathrm{n} 1+\mathrm{n} 2-2$ dengan taraf signifikansinya $5 \%$. Karena $t_{\text {hitung }}$ lebih besar dari $t_{\text {tabel }}$ pada taraf sisgnifikan 5\% maka Ha diterima dan H0 ditolak. Dengan demikian dapat disimpulkan bahwa terdapat pengaruh model pembelajaran learning cycle $5 E$ terhadap peningkatan minat dan hasil belajar peserta didik kelas XI SMA Negeri 8 Mataram tahun ajaran 2018/2019.

\section{UCAPAN TERIMA KASIH}

Penulis mengucapkan ucapan terima kasih kepada semua pihak yang telah membantu penyusun artikel ini. Semoga apa yang kita lakukan menjadi amal jariyah dan bermanfaat bagi semua pembaca. 


\section{DAFTAR PUSTAKA}

Asriyadin, Yus'iran, Hafidah Nurul Fikri, (2016). Pengaruh Model Learning Cycle 5E Terhadap Hasil Belajar Fisika Siswa Kelas X Sman 1 Madapangga Tahun Pelajaran 2016/2017. Jurnal Pendidikan MIPA, 6(2), 63.

Eva M. Ginting dan Harin Sundari, (2012). Pengaruh Model Pembelajaran Learning Cyclnne Berbasis Eksperimen Terhadaphasil Belajar Siswa Pada Materi Pokok Zat Dan Wujudnya. jurnal pendidikan fisika ,1(2), 62.

Slameto, (2013). Belajar dan Faktor-faktor yang Mempengaruhinya, Jakarta: Rineka Cipta.

Nenen Shanti W, Ukit, (2017). Peningatkan Motivasi Dan Hasil Belajar Siswa Melalui Penerapan Model Pembelajaran Siklus Belajar 5E (Learning Cyclle 5E) Pada Konsep Sistem Ekskresi. Jurnal Program Studi Pendidikan Biologi, 8(1), 19.

Ira Nofita Sari, Dwi Fajar Saputri, Yupensius Beno,(2016). Penerapan Model Learning Cycle 5E Dalammateri Besaran Dan Turunan Di Kelas VII SMP NEGERI SENGAH TEMILA. Jurnal Ilmiah Pendidikan Fisika, 5(2), 281.

Sugiyono, (2010). Metode Penelitian Pendidikan Pendekatan Kuantitatif Kualitatatif dan R\&D. Bandung: Alfabeta.

Sugiyono, (2016). Metode Penelitian Pendidikan Pendekatan Kuantitatif Kualitatatif dan R\&D. Bandung: Alfabeta.

Nismalasari, Santiani, dan H.Mukhlis Rohmadi, (92). Penerapan Model Pembelajaran Learning Cycle Terhadap Keterampilan Proses Sains Dan Hasil Belajar Siswa Pada Pokok Bahasan Getaran Harmonis. 4(2), 92.

Niluh Asriniasih, Sugiarti, Netti Herawati, (2014). Pengaruh Model Pembelajaran Learning Cycle 5E Melalui Pendekatan Kontekstual Terhadap Hasil Belajar IPA Kimia Siswa Kelas VIII SMPN 30 Makassar (Studi pada Materi Pokok Bahan Kimia. Jurnal Chemica, $15(1), 9$.

Helni Senindra, Muhammad Muslim, dan Apit Fathurohman, (2016). Pengaruh Model Pembelajaran Learning Cycle 5E Terhadap Hasil Belajar Fisika Siswa Kelas X MAN Prabumulih. Jurnal Inovasi Dan Pembelajaran Fisika, 3.

M A Tyas , Mulyono, Sugiman, (2015). Keeektifan Model Pembelajaran Learning Cycle 7e Terhadap Minat Belajar Dan Pemahaman Konsep Matematika Siswa Kelas X. Unnes Journal Of Mathematics Education, 4(3), 262. 